\title{
RANCANG BANGUN APLIKASI MULTIMEDIA SEBAGAI PANDUAN DALAM PELAKSANAAN UPACARA BENDERA DI SEKOLAH MENENGAH ATAS
}

\author{
Yasni Djamain, Intan Ratna Sari Yanti, Dwina Kuswardani \\ Program Studi Sarjana Teknik Informatika, Sekolah Tinggi Teknik PLN Jakarta \\ Jalan Lingkar Luar Barat Menara PLN Cengkareng Jakarta Barat \\ e-mail: yasni@sttpln.ac.id, intanratna71@yahoo.com, dwinakuswdn@yahoo.com
}

\begin{abstract}
ABSTRAK
Multimedia mengubah sajian tradisional komputer yang berupa teks, menjadi suatu media yang menarik perhatian dan keingintahuan. Penerimaan informasi menjadi semakin baik, dan jika disusun secara baik, multimedia juga bisa menjadi amat menghibur. Multimedia memiliki banyak manfaat dalam semua bidang kehidupan manusia. Di bidang bisnis, multimedia dimanfaatkan sebagai iklan yang kreatif untuk menarik konsumen. Selain itu dengan multimedia, informasi yang disampaikan menjadi lengkap dan mudah dimengerti. Penempatan Multimedia dapat dilaksanakan dimana saja selama peran masyarakat membutuhkan akses menuju sumber media yang membutuhkan informasi elektronik. Peran Multimedia juga menjembatani dan menjangkau masyarakat yang sedikit sukar dalam penerimaan terhadap bentuk penyampaian standard komputer kedalam bentuk yang lebih mudah dapat diterima dan mudah digunakan. Rancang bangun Panduan Upacara Bendera Berbasis Multimedia Dalam Pelaksanaan Upacara Bendera di Sekolah Menengah Atas (SMA) yang bertujuan sebagai salah satu alternative untuk membuat upacara bendera menjadi lebih menarik bagi siswa SMA. Upacara bendera setiap hari Senin di sekolah bertujuan untuk melatih kedisiplinan siswa serta memupuk rasa cinta tanah air dan bangsa ataupun menumbuhkan semangat jiwa nasionalisme. Upacara bendera setiap hari Senin di sekolah bertujuan untuk melatih kedisiplinan siswa serta memupuk rasa cinta tanah air dan bangsa ataupun menumbuhkan semangat jiwa nasionalisme. Seiring dengan perkembangan Teknologi Informasi dan Komunikasi dengan memanfaatkan multimedia maka pelaksanaan upacara bendera di setiap sekolah setiap Hari Senin pagi diharapkan dapat lebih menarik.
\end{abstract}

Kata Kunci: multimedia, upacara bendera, panduan, sekolah menengah atas

\section{PENDAHULUAN}

\section{Latar Belakang}

Pada hakekatnya upacara bendera adalah pencerminan dari nilai-nilai budaya bangsa yang merupakan salah satu pancaran peradaban bangsa, hal ini merupakan ciri khas yang membedakan dengan bangsa lain. Sejak zaman nenek moyang bangsa Indonesia telah melaksanakan upacara, seperti upacara selamatan kelahiran, upacara selamatan panen. Oleh karena itu di sekolah-sekolah wajib diadakan Upacara Bendera, baik itu Upacara Penaikan maupun Penurunan Bendera. Dasar hukum diadakannya Upacara Bendera di sekolah itu sendiri dilandasi oleh Pancasila, UUD 1945 (tentang Sistem Pendidikan Nasional) dan Inpres No. 14 tahun 1981 (tentang Urutan Upacara Bendera).

Pemanfaatan multimedia dalam semua bidang kehidupan manusia diantaranya bisnis, multimedia dimanfaatkan sebagai iklan yang kreatif untuk menarik konsumen. Selain itu dengan multimedia, informasi yang disampaikan menjadi lengkap dan mudah dimengerti. Penempatan Multimedia dapat dilaksanakan dimana saja selama peran masyarakat membutuhkan akses menuju sumber media yang membutuhkan informasi elektronik. Multimedia mengubah sajian tradisional komputer yang berupa teks, menjadi suatu media yang menarik perhatian dan keingintahuan. Penerimaan informasi menjadi semakin baik, dan jika disusun secara baik, multimedia juga bisa menjadi amat menghibur. Peran Multimedia juga menjembatani dan menjangkau masyarakat yang sedikit sukar dalam penerimaan terhadap bentuk penyampaian standard komputer kedalam bentuk yang lebih mudah dapat diterima dan mudah digunakan.

\section{Rumusan Masalah}

Berdasarkan latar belakang di atas maka perumusan masalah adalah bagaimana merancang aplikasi multimedia pelaksanaan upacara bendera di sekolah?

\section{Maksud dan Tujuan Penelitian}

Panduan Pelaksanaan Upacara Bendera ini tentunya memiliki maksud dan tujuan, diantaranya:

Untuk memperoleh suasana yang khidmat, tertib, dan menuntut pemusatan perhatian dari seluruh peserta.

Membuat para siswa lebih menghayati perjuangan dengan ditampilkannya beberapa video tentang perjuangan ketika dinyanyikan lagu wajib.

Memandu seluruh peserta upacara selama kegiatan berlangsung

Tercapainya keseragaman pelaksanaan upacara bendera dengan sekolah lain jika aplikasi multimedia ini digunakan secara luas nantinya.

\section{Manfaat Penelitian}

Manfaat yang dapat diambil dalam penelitian ini adalah pelaksanaan upacara bendera dapat lebih menarik dan terarah sesuai dengan panduan dalam multimedia. Adapun luaran yang ditargetkan dari penelitian ini adalah: 
Aplikas berbasis multimedia yang dapat digunakan oleh semua peserta upacara yang berminat untuk menggunakannya.

Publikasi di jurnal nasional sehingga dapat digunakan untuk merancangg aplikasi berbasis multimedia lainnya.

\section{TINJAUAN PUSTAKA}

\section{Tata Cara Upacara Bendera}

Menurut arti bahasa, Tata Upacara terdiri dari beberapa kata. 1) Tata artinya kaidah, aturan, dan susunan; cara menyusun; sistem; dan 2) Upacara artinya perbuatan atau perayaan yang dilakukan atau diadakan sehubungan dengan peristiwa penting. Jadi menurut bahasa arti dari Tata Upaca Bendera adalah susunan sebuah tindakan/perbuatan yang diadakan sehubungan dengan peristiwa penting. Menurut Kamus Besar Bahasa Indonesia (KBBI) sendiri Upacara Bendera berarti upacara resmi secara militer yg dilakukan oleh instansi pemerintah pd setiap tanggal 17 dan pada harihari nasional, disertai penaikan bendera Sang Merah Putih.

Pada hakekatnya upacara bendera adalah pencerminan dari nilai-nilai budaya bangsa yang merupakan salah satu pancaran peradaban bangsa, hal ini merupakan ciri khas yang membedakan dengan bangsa lain. Sejak zaman nenek moyang bangsa Indonesia telah melaksanakan upacara, seperti upacara selamatan kelahiran, upacara selamatan panen. Oleh karena itu di sekolah-sekolah wajib dadakan Upacara Bendera, baik itu Upacara Penaikan maupun Penurunan Bendera. Dasar hukum diadakannya Upacara Bendera di sekolah itu sendiri dilandasi oleh Pancasila, UUD 1945 (tentang Sistem Pendidikan Nasional) dan Inpres No. 14 tahun 1981 (tentang Urutan Upacara Bendera).

\section{Maksud dan Tujuan Upacara Bendera}

Pelaksanaan Upacara Bendera ini tentunya memiliki maksud dan tujuan, diantaranya:

a. Menjadikan sekolah memiliki situasi yang dinamis dalam segala aspek kehidupan bagi para siswa, guru, pembina dan kepala sekolah. Sehingga sekolah memiliki daya kemampuan dan ketangguhan terhadap gangguan-gangguan negatif baik dari dalam maupun luar sekolah, yang akan dapat mengganggu kelancaran proses belajar mengajar di sekolah.

b. Untuk memperoleh suasana yang khidmat tertib, dan menuntut pemusatan perhatian dari seluruh peserta, maka disusunlah petunjuk pelaksanaan kegiatan ini.

Dalam Upacara Bendera terdapat beberapa jabatan, seperti:

- Pembina Upacara

- Pemimpin Upacara

- Pengatur Upacara

- Pembawa Upacara
Sedangkan untuk petugasnya adalah:

- Pembawa naskah Pancasila

- Pembaca Teks Pembukaan Undang-Undang Dasar 1945

- Pembaca Do'a

- Pemimpin Lagu

- Kelompok Pengibar / Penurun Bendera

- Kelompok Pembawa Lagu

- Cadangan tiap perangkat

Beberapa perlengkapan yang harus disiapkan sebelum dilaksanakan upacara bendera adalah sebagai berikut:

- Bendera Merah Putih, dengan ukuran perbandingan 2 : 3 , ukuran terbesar $2 \times 3$ meter dan ukuran terkecil $1 \times 1,5$ meter.

- $\quad$ Tiang Bendera, dengan tinggi minimal 5 meter maksimal 17 meter, untuk perbandingan bendera dengan tiang adalah $1: 5$.

- Tali Bendera, diusahakan tali yang digunakan adalah tali layar dan bukan tali plastik.

- Naskah-naskah, seperti naskah Pancasila, Naskah Pembukaan Undang-Undang Dasar 1945, Naskah Janji Siswa, Naskah Do'a dan Naskah Susunan Acara.

Tata Upacara Bendera atau Susunan Upacara Bendera di Sekolah sendiri sebenarnya sudah diatur oleh pemerintah, yang disebut Tata Upacara Sekolah (TUS). Tata Upacara tersebut diatur dalam buku Petunjuk Pelaksanaan Upacara Bendera di Sekolah Tahun 1997 (Depdiknas) susunan upacara tersusun sebagai berikut:

- Pembina Upacara memasuki lapangan upacara

- Penghormatan Umum

- Laporan Pemimpin Upacara

- Pengibaran Bendera Sang Merah Putih

- Mengheningkan Cipta

- Pembacaan Teks Pembukaan UUD 1945

- Pembacaan Teks Pancasila

- Amanat Pembina Upacara

- Pembacaan Doa

- Laporan Pemimpin Upacara

- Penghormatan Umum

- Pembina Upacara meninggalkan lapangan upacara

Upacara selesai, barisan dibubarkan

- Penghormatan kepada Pemimpin Upacara

\section{Manfaat Upacara Bendera}

Upacara bendera memberikan manfaat kepada para siswa. Adapun manfaat yang didapatkan menurut Direktoran Pembinaan Kesiswaan Dikdasmen, Dikbud 1998 adalah sebagai berikut:

- Membiasakan disiplin

- Dengan mengikuti upacara bendera, kita akan dilatih untuk tertib dan disiplin. Karena dalam upacara bendera, setiap peserta upacara wajib mengikuti susunan upacara dengan tertib. Bahkan ada sekolah yang menempatkan siswa-siswinya di posisi yang khusus jika terlambat mengikuti upacara.

- Menumbuhkan jiwa kepemimpinan

- Pada upacara bendera, biasanya ada jadwal 
bergantian siswa-siswi yang menjadi petugas upacara. Salah satunya adalah menjadi pemimpin upacara. Saat menjadi pemimpin upacara, siswa tersebut dituntut bisa memimpin jalannya upacara dengan baik. Dengan inilah, para siswa dapat merasakan dan berlatih untuk menjadi seorang pemimpin.

- Membiasakan berpenampilan rapi

- Ketika upacara bendera hari Senin atau hari besar yang lain, seperti hari pahlawan dan sebagainya, atribut yang khas dan wajib dipakai adalah topi. Selain itu atribut lain seperti dasi atau sepatu harus hitam juga lebih diperhatikan di hari tersebut. Oleh sebab itu, melalui upacara bendera pula para pelajar berlatih bagaimana untuk selalu berpenampilan rapi. Layaknya penampilan,pelajar yang seharusnya.

- Meningkatkan kekompakan dan kebersamaan

- Dalam mengikuti kegiatan upacara bendera, peserta upacara harus kompak dalam mengikuti aturan dan aba-aba dari petugas upacara. Menunjukkan kebersamaan selama mengikuti upacara, seluruh peserta upacara merasakan hal yang sama, wajib mengikuti susunan upacara dari awal sampai akhir.

- Menumbuhkan jiwa nasionalisme

- Upacara bendera diharapkan bukan hanya menjadi ritual semata. Namun dengan kegiatan upacara bendera, semoga bisa menumbuhkan sikap nasionalisme dalam benak para pelajar.

\section{Pengertian Multimedia}

Menurut kamus umum Bahasa Indonesia secara umum, media berarti suatu alat, perantara atau penghubung. Media dalam cakupan lebih luas adalah sarana komunikasi yang digunakan untuk menyebarkan informasi kepada masyarakat. Multimedia berasal dari dua kata yaitu multi dan media, multi berarti beberapa dan media berarti sarana atau alat. Kata multimedia sendiri sebenarnya sudah ada sebelum komputer seperti saat ini dan lebih banyak dipakai di dunia hiburan seperti pementasan teater multimedia yang sudah ada sejak lama yaitu satu bentuk pementasan teater yang didukung oleh banyak alat bantu seperti pengeras suara, lampu panggung, gambar bergerak pada latar dan sebagainya.

Multimedia merupakan perkembangan teknologi komputer yang saat ini menjadi perhatian luas. Istilah multimedia digunakan untuk menjelasan suatu sistem yang teridri dari perangkat keras (hardware) dan perangkat lunak (software), serta alat bantu lain yang berupa televisi, monitor video, dan sistem piringan optik atau sistem stereo yang semuanya dikombinasikan untuk menghasilkan suatu penyajian audio visual penuh (Mc Leod, 1996).

Multimedia diartikan sebagai kombinasi dari macam - macam objek multimedia, yaitu teks, image, animasi, audio, video, dan link interaktif untuk menyajikan informasi. Sedangkan Gayeski (1993) mendefinisikan multimedia sebagai kumpulan media berbasis komputer dan sistem komunikasi yang berperan untuk membina, menyimpan, mengirim dan menerima informasi yang berisi teks, grafik, audio dan sebagainya (Sutopo, 2003).

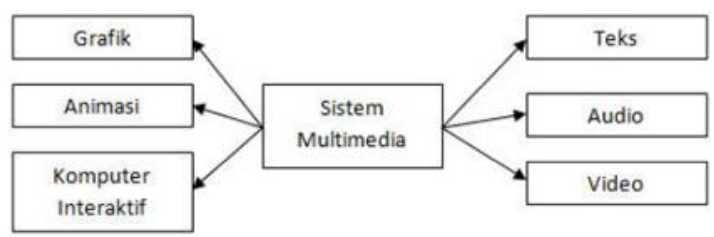

Gambar 1. Keterkaitan antara Multimedia

Dari beberapa pernyataan di atas dapat dikatakan bahwa multimedia merupakan penyatuan dua atau lebih media komunikasi seperti teks, grafik, animasi, audio dan video dengan ciri-ciri interaktif komputer untuk menghasilkan satu tampilan yang menarik. Pada awal tahun 1990-an yang dimaksud dengan multimedia adalah kombinasi antara teks dan gambar. Seiring dengan berkembangnya teknologi komputer dari waktu ke waktu, saat ini multimedia tidak hanya merupakan kombinasi dari teks dan gambar saja, melainkan telah menggunakan animasi, video, dan suara.

\section{Tahap Pengembangan Multimedia}

Pengembangan multimedia dilakukan berdasarkan enam tahap. Adapun penjelasan dari langkah-langkah pengembangan multimedia pada gambar di atas adalah sebagai berikut:

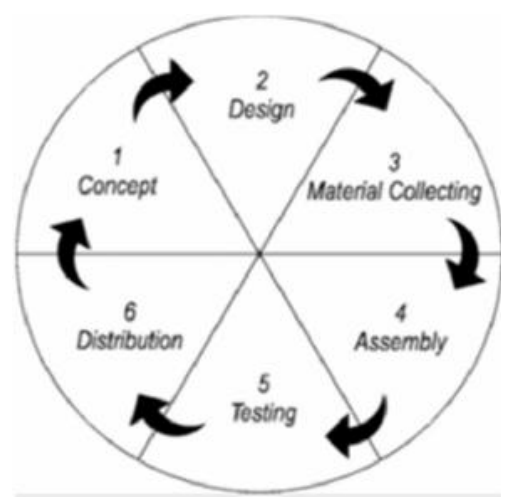

Gambar 2. Tahap Pengembangan Multimedia (Luther, 1994)

Adapun penjelasannya adalah sebagai berikut:

a. Concept

Tahap concept (konsep) yaitu menentukan tujuan, termasuk identifikasi pengguna, macam aplikasi (persentasi, interaktif, dan lain-lain), tujuan aplikasi (informasi, hiburan, pelatihan, dan lain-lain) dan spesifikasi umum. Dasar aturan untuk perancangan juga ditentukan pada tahap ini, seperti ukuran aplikasi, target, dan lain- lain.

\section{b. Design}

Maksud dari tahapan design (perancangan) adalah membuat spesifikasi secara rinci mengenai arstitektur proyek, gaya, dan kebutuhan material untuk proyek. Spesifikasi dibuat cukup rinci sehingga pada tahap berikutnya, yaitu material 
collecting dan assembly tidak diperlukan keputusan baru, tetapi menggunakan apa yang sudah ditentukan pada tahap design. Namun demikian, sering terjadi penambahan bahan atau bagian aplikasi ditambah, dihilangkan, atau diubah pada awal pengerjaan proyek.

\section{c. Material Collecting}

Material collecting (pengumpulan bahan) dapat dikerjakan paralel dengan tahap assembly. Pada tahap ini dilakukan pengumpulan bahan seperti clipart image, animasi, audio, berikut pembuatan gambar grafik, foto, audio, dan lain-lain yang diperlukan untuk tahap berikutnya. Bahan yang diperlukan dalam multimedia dapat diperoleh dari sumber-sumber seperti library, bahan yang sudah ada pada pihak lain, atau pembuatan khusus yang dilakukan oleh pihak luar.

\section{d. Assembly}

Tahap assembly (pembuatan) merupakan tahap dimana seluruh objek multimedia dibuat. Pembuatan aplikasi berdasarkan story board, flowchart view, struktur navigasi, atau diagram objek yang berasal dari tahap design. Contohnya pada pembuatan presentasi, pembuatan dilakukan dengan memasukkan data yang digunakan untuk berbagai tampilan, serta menentukan screen dengan urutannya.

\section{e. Testing}

Testing dilakukan setelah selesai tahap pembuatan dan seluruh data telah dimasukkan. Pertama-tama dilakukan testing secara modular untuk memastikanapakah hasilnya seperti yang diinginkan. Beberapa sistem mempunyai fitur yang dapat memberikan informasi bila terjadi kesalahan pada program. Suatu hal yang tidak kurang penting adalah aplikasi harus dapat berjalan dengan baik dilingkungan user. User merasakan kemudahan serta manfaat dari aplikasi tersebut dan dapat menggunakan sendiri terutama untuk aplikasi interaktif.

\section{f. Distribution}

Bila aplikasi multimedia akan digunakan dengan mesin yang berbeda, penggandaan menggunakan floppy disk, CD-ROM, tape, atau distribusi dengan jaringan sangat diperlukan. Suatu aplikasi biasanya memerlukan banyak file yang berbeda, dan kadang-kadang mempunyai ukuran sangat besar.

\section{Multimedia Content Production}

Multimedia adalah penggunaan dan pemrosesan beberapa media (text, audio, graphics, animation, video, and interactivity) yang berbeda untuk menyampaikan informasi atau menghasilkan produk multimedia (music, video, film, game, entertaiment, dan lain-lain) Atau penggunaan sejumlah teknologi yang berbeda yang memungkinkan untuk menggabungkan media (text, audio, graphics, animation, video, and interactivity) dengan cara yang baru untuk tujuan komunikasi. Dalam kategori ini media yang digunakan (tampak pada Gambar 3) adalah media text, media audio, media video, media animasi, media graph / image, media interactivity, dan media special effect.

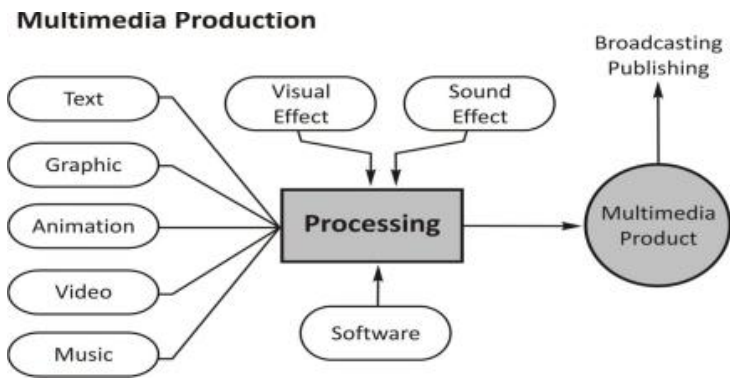

Gambar 3. Multimedia Production

7. Multimedia Linear dan Multimedia Interaktif Multimedia terbagi menjadi dua kategori, yaitu: multimedia linear dan multimedia interaktif.

\section{Multimedia linear}

Multimedia linear dimulai dari satu posisi awal menuju ke suatu posisi akhir dengan sedikit atau tanpa interferensi pemakai. Misalnya televisi, film, majalah, koran. Pemakai hanya menjadi penonton dan menikmati produk multimedia yang disajikan dari awal hingga akhir.

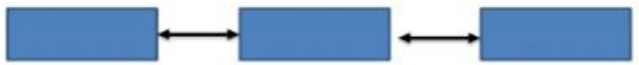

Gambar 4. Diagram Multimedia Linear

Ciri-ciri dari multimedia linear :

- Sederhana

- Bersifat logical

- Ideal untuk produk yang kecil

\section{Multimedia interaktif}

Multimedia interaktif adalah integrasi digital antara text, graphics, animasi, audio, gambar tak bergerak (still images) dan bergerak (motion video) dimana disediakan kontrol terhadap konten dan interaksi tingkat tinggi bagi pemakai individu dan aplikasi multimedia. Misalnya game, multimedia pembelajaran, website. Pengguna dapat mengontrol apa dan kapan elemen-elemen multimedia akan dikirimkan atau ditampilkan.

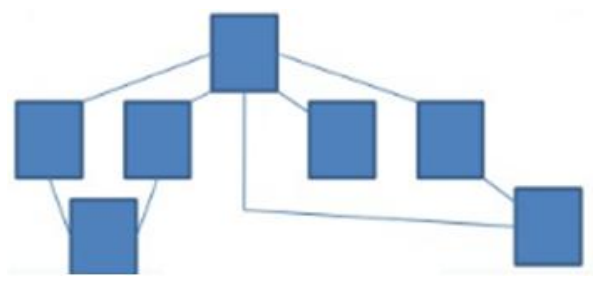

Gambar 5. Diagram Multimedia Interaktif

\section{Macromedia Flash 8}

Aplikasi Macromedia Flash 8 adalah sebuah program animasi yang telah banyak digunakan oleh designer untuk menghasilkan design yang professional. Diantara program-program animasi yang ada, program Macromedia Flash merupakan program yang paling fleksibel untuk membuat 
animasi, mulai dari animasi sederhana sampai animasi kompleks yang meliputi aplikasi web yang dinamis dan interaktif seperti ecommerece atau toko online di internet dan multimedia untuk pembuatan sebuah sistem informasi sehingga banyak yang menggunakan program tersebut. Fungsi program Macromedia Flash 8 adalah membuat animasi, baik animasi interaktif maupun animasi non interaktif.

Penggunaan program Macromedia Flash 8 dalam merancang aplikasi multimedia berdasarkan keunggulan yang dimiliki program flash dibandingkan dengan program yang sejenis lainnya. Keunggulannya sebagai berikut:

- Dapat membuat tombol interaktif dengan sebuah movie atau obj ek yang lain.

- Dapat membuat perubahan transparansi warna dalam movie.

- Dapat membuat gerakan animasi dari satu bentuk ke bentuk lain.

- Dapat membuat gerakan animasi dengan mengikuti alur yang telah ditetapkan.

- Dapat dikonversi dan dipublikasi (publish) ke dalam beberapa tipe diantaranya: .swf, .html, .gif, .png, .exe, .mov.

\section{METODE PENELITIAN}

Metodologi penelitian ini merupakan tahaptahap yang dilakukan penulis dengan melakukan penelitian. Adapun garis besar dari metodologi penelitian ini akan digambarkan secara umum dalam diagram berikut :
Pada bagian ini akan dijelaskan kegiatan sistematis dengan serangkaian proses yang dilakukan secara terstruktur. Setiap tahapan proses tersebut akan saling berhubungan, dimana suatu proses yang dilakukan merupakan bagian dari tahapan yang menentukan proses selanjutnya.

\section{Analisa Sistem Berjalan}

Sejak zaman nenek moyang bangsa Indonesia telah melaksanakan upacara, seperti upacara selamatan kelahiran, upacara selamatan panen. Oleh karena itu di sekolah-sekolah wajib dadakan Upacara Bendera, baik itu Upacara Penaikan maupun Penurunan Bendera. Dasar hukum diadakannya Upacara Bendera di sekolah itu sendiri dilandasi oleh Pancasila, UUD 1945 (tentang Sistem Pendidikan Nasional) dan Inpres No. 14 tahun 1981 (tentang Urutan Upacara Bendera).

\section{Kendala yang dihadapi}

Dalam upacara bendera konvensional ini tidak semua siswa dapat mengikuti pelaksaan upacara bendera secara baik. Terutama baris bagian belakang. Selain kegiatan upacara terpusat di barisan depan, kondisi lapangan yang panas ketika pelaksanaan upacara bendera di pagi hari dapat membuat beberapa siswa tidak konsentrasi mengikuti jalannya upacara. Selain itu, banyaknya kegiatan yang harus dilakukan memungkinkan satu kegiatan memerlukan waktu lebih sehingga membuat pelaksanaan kegiatan upacara bendera berjalan lebih lama. Dengan adanya aplikasi ini diharapkan urutan dan waktu pelaksanaan upacara bendera dapat diprediksi.

\section{Alternatif Penyelesaian Masalah}

Sistem yang akan dibangun merupakan suatu sistem yang membantu dalam pelaksaan upacara bendera. Aplikasi multimedia yang menampilkan urutan pelaksanaan dan waktu untuk masingmasing kegiatan tersebut.

\section{HASIL DAN PEMBAHASAN}

Berdasarkan perancangan aplikasi Panduan Upacara Bendera, secara garis besar aplikasi ini berperan untuk membantu user. Dengan bantuan teks, warna dan animasi maka dapat memudahkan pengguna dalam pemakaian multimedia karena terlihat lebih menarik dan memberikan kemudahan kepada peserta untuk mengikuti urutan pelaksanaan upacara bendera. Adapun hasil tampilan dari panduan upacara adalah sebagai berikut:

a. Tampilan awal

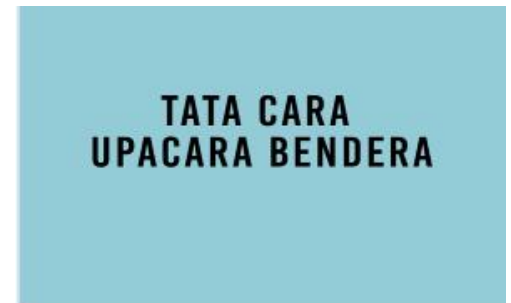

Gambar 7. Tampilan awal 
b. Petugas Upacara

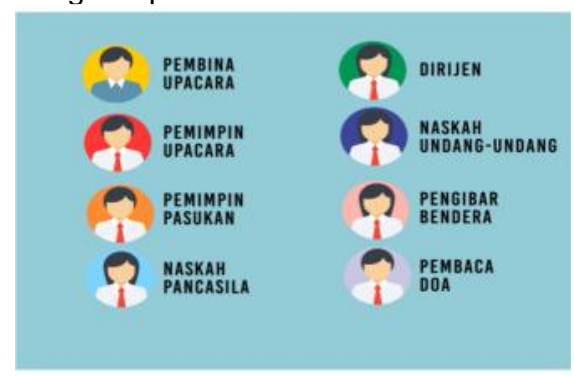

Gambar 8. Petugas Upacara

c. Persiapan Barisan

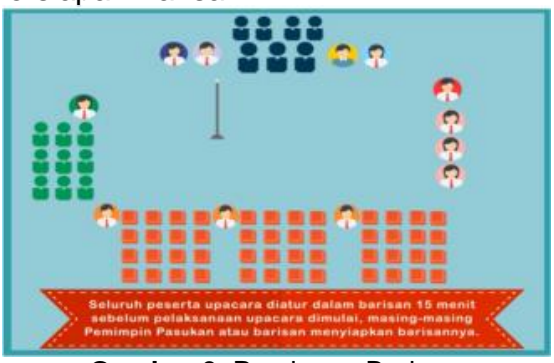

Gambar 9. Persiapan Barisan

d. Pembina Upacara memasuki lapangan

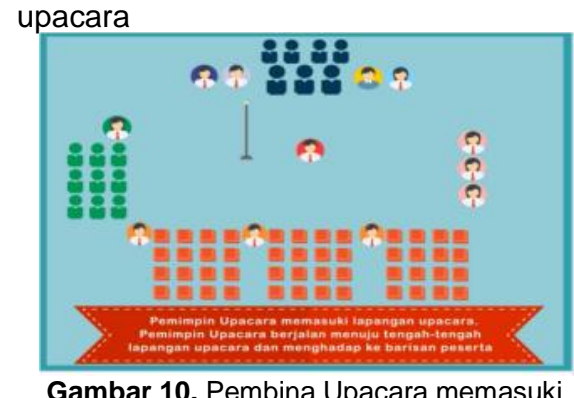

Gambar 10. Pembina Upacara memasuki lapangan upacara

e. Penghormatan Umum

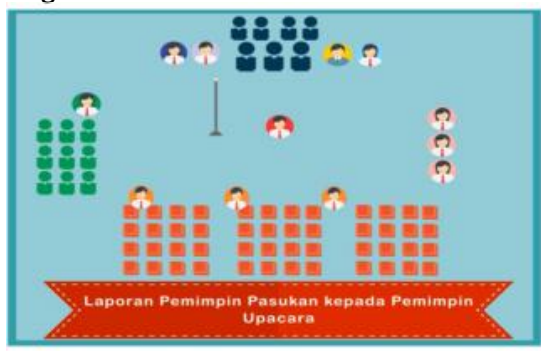

Gambar 11. Penghormatan Umum

f. Pengibaran Bendera Sang Merah Putih

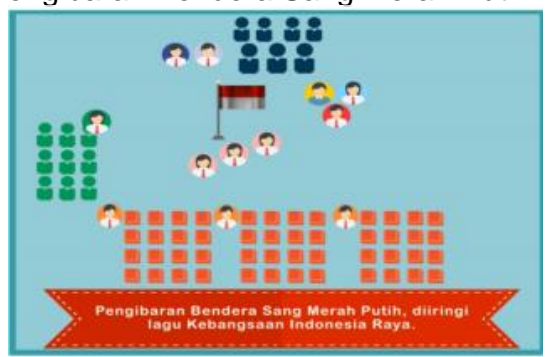

Gambar 12. Pengibaran Bendera Sang Merah Putih g.

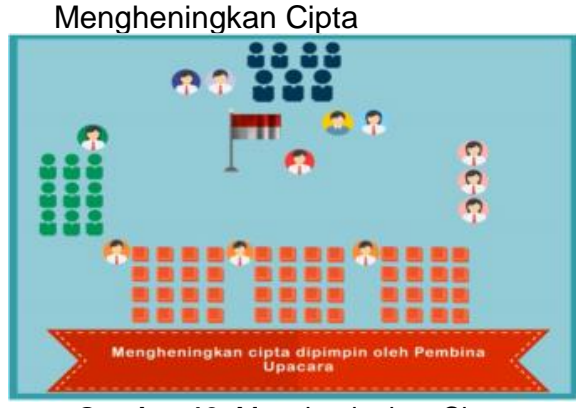

Gambar 13. Mengheningkan Cipta

h. Pembina Upacara meninggalkan lapangan upacara. Upacara selesai.

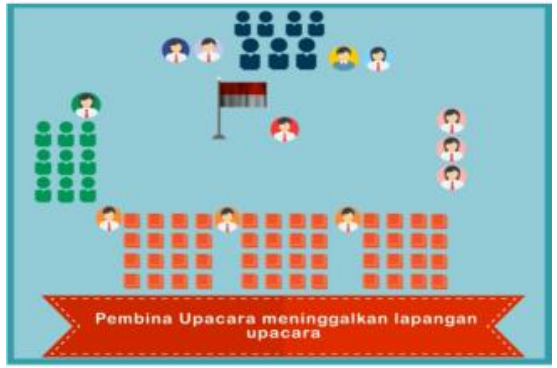

Gambar 14. Pembina Upacara meninggalkan lapangan upacara. Upacara selesai.

\section{PENUTUP}

\section{Kesimpulan}

Dari penelitian yang dilakukan dapat diambil beberapa kesimpulan yaitu:

- Para guru sangat mendukung mengenai Pemanfaatan Panduan Upacara Bendera Berbasis Multimedia Dalam Pelaksanaan Upacara Bendera di Sekolah Menengah Atas (SMA).

- $\quad$ Aplikasi ini sebagai salah satu alternatif untuk membuat upacara bendera menjadi lebih menarik bagi siswa SMA.

\section{Saran}

Adapun saran adalah sebagai berikut:

- Ketersedian peralatan multimedia seperti proyektor, layar, speaker dan sebagainya ketika pelaksanaan uacara bendera sangat mendukung jalannya upacara bendera lebih teratur dan dapat diikuti oleh seluruh peserta upacara.

- Perlunya pemanfaatan multimedia untuk mendukung pelaksanaan proses belajar mengajar di sekolah sehingga multimedia dapat dimanfaatkan secara maksimal.

\section{DAFTAR PUSTAKA}

Agus Suheri. (2006)."Animasi Multimedia Pembelajaran" Jakarta : Elec media Komputindo.

Astuti, Dwi. 2006. "Teknik Membuat Animasi Professional Menggunakan Macromedia Flash 8". Yogyakarta: ANDI Offset. Sutopo, A. H., 
2003, Multimedia Interaktif dengan Flash, Graha IImu, Yogyakarta

Arsyad, Azhar. 2004. Media Pembelajaran. Edisi 1, Cetakan Ke-5. Jakarta: PT Grafindo Persada. Jakarta.

Juhaeri . 2007 . "Pengantar Multimedia Untuk Media Pembelajaran"

Dhani Yudhiantoro. (2007)."Macromedia Flash professional 8" Yogyakarta : Andi Offset.

http://www.pustakasekolah.com/tata-urutan-

lengkap-upacara-umum.html

http://ppikabtasikmalaya.wordpress.com/aturantata-cara/tata-upacara-bendera-tub/ http://densusnadi.blogspot.com/2010/04/tataupacara-sekolah-tus.html

http://www.brigaspad.org/2012/03/perbedaan-tataupacara-militer-dengan.htm 